\title{
Human papillomavirus vaccination in national immunization programs: impact and perspectives
}

\author{
Vacinação contra o papilomavírus humano em programas nacionais de \\ imunização: impacto e perspectivas
}

\author{
Anna Caroline Grigio Solano de Freitas ${ }^{1}$, Ayrton John Macedo Goncalez ${ }^{2}$, \\ Gabriel Chicote Guimarães ${ }^{2}$, Luisa Lina Villa ${ }^{3}$
}

Freitas ACGS, Goncalez AJM, Guimarães GC, Villa LL. Human papillomavirus vaccination in national immunization programs: impact and perspectives / Vacinação contra o papilomavírus humano em programas nacionais de imunização: impacto e perspectivas. Rev Med (São Paulo). 2018 jan.-fev.;97(1):81-97.

\begin{abstract}
Human Papillomaviruses are present in virtually all cases of cervical cancer and are also linked with anogenital warts and other precancerous lesions which can be primarily prevented by HPV vaccination. We searched the PubMed, Scopus, Web of Science and Embase databases (between January 1st, 2011 and February 28th, 2017) and WHO (World Health Organization) and countries' health organizations websites for data on HPV vaccination programs and its effectiveness. For the review on the Brazilian Immunization program, we additionally searched SciELO database and websites of the Brazilian Ministry of Health and the Information System of the National Immunization Program (SI-PNI). As of April 2017, about 40\% of the countries had introduced HPV vaccines in their national immunization programs, targeting almost always children and teenage females between 9 and 13 years of age. Most of these are high-income countries but low- and middle-income countries are recently implementing the vaccination program with financial support of public and private organizations. Since the introduction of HPV vaccination, numerous articles present data on its effectiveness in real world supporting the effectiveness of an immunization program in the prevention of HPV infection and related diseases
\end{abstract}

in both genders. The Brazilian HPV vaccination program began in 2014 for 9-13 years old girls and has recently been expanded to include boys and young males. This review aims to update information on HPV vaccination programs worldwide highlighting the Brazilian immunization program. Data on the impact and effectiveness of HPV vaccines on infection and related diseases is presented. Moreover, the reasons for different coverage rates, reflected in low-vaccine uptake, are discussed. Finally, the present review addresses the socioeconomic barriers as well as the key determinants of long-term program success and strategies to improve access and adherence to HPV vaccination.

Keywords: Condylomata acuminata; Papillomaviridae; Mass vaccination; Papillomavirus vaccines; Health impact assessment; Uterine cervical neoplasms.

RESUMO: O Papilomavírus Humano (HPV) está presente em praticamente todos os casos de câncer do colo do útero e também em verrugas anogenitais e outras lesões pré-cancerígenas diversas, que podem ser prevenidos primariamente via vacinação. Até abril de 2017 , cerca de $40 \%$ dos países já haviam introduzido a vacina

Agências de fomento: CNPq 573799/2008-3; FAPESP 2008/57889-1.

Artigo desenvolvido na Disciplina Optativa "Abordagem Prática da Escrita Científica” sob coordenação da Revista de Medicina do DC-FMUSP.

1. Faculdade de Medicina FMUSP, Universidade de São Paulo. Bacharel em Direito e graduanda em Medicina na FMUSP. Email: anna.freitas@fm.usp.br, http://orcid.org/0000-0002-3759-7758.

2. Faculdade de Medicina FMUSP, Universidade de São Paulo. Graduando em Medicina na FMUSP. Email: ayrton.goncalez@fm.usp. br, http://orcid.org/0000-0001-9707-5487; g.guimaraes@fm.usp.br, http://orcid.org/0000-0003-3638-4715.

3. Departamento de Radiologia e Oncologia, Faculdade de Medicina FMUSP, Universidade de São Paulo. Instituto do Câncer do Estado de São Paulo. Professora Associada, PhD. Email: villa@hc.fm.usp.br, http://orcid.org/0000-0003-4074-2335.

Endereço para correspondência: Anna Caroline Grigio Solano de Freitas. Faculdade de Medicina - USP. Av. Dr. Arnaldo, 455.

Cerqueira César - São Paulo, SP, BR. CEP: 01246-903. 
Freitas ACGS, et al. Human papillomavirus vaccination in national immunization programs.

de HPV em seus programas nacionais de imunização, tendo por alvo quase sempre meninas entre 9 e 13 anos de idade. A maioria desses países são de alta renda, mas países de média e baixa renda têm implementado recentemente programas de vacinação com o apoio de organizações de financiamento públicas e privadas. Desde a introdução da vacinação de HPV, inúmeros artigos apresentam dados sobre sua efetividade no mundo real, apoiando a efetividade de um programa de imunização na prevenção da infecção e na redução das doenças relacionadas ao HPV em ambos os sexos. O programa brasileiro de vacinação contra o HPV iniciou-se em 2014 para meninas de 9 a 13 anos de idade e, recentemente, foi ampliado para meninos. Este artigo de revisão visa atualizar os dados de implementação de vacina de HPV em

\section{INTRODUCTION}

$\mathrm{H}$ uman papillomaviruses (HPV) are the most common sexually transmitted virus, with infection occurring mainly through sexual intercourse and soon after the first exposure ${ }^{1,2}$, with a lifetime probability of infection as high as $80 \%{ }^{3}$. Most infections, which occur in epithelial cells ${ }^{4}$, are asymptomatic and self-limited, but persistent and recurrent infections can lead to HPV-related lesions and cancer ${ }^{3,5}$. In many women, natural infection diferentes países do mundo, enfatizando o programa brasileiro. Além disso, são apresentados os dados de impacto e efetividade da vacina de HPV em relação à redução de infecções e doenças causados pelos tipos de HPV contidos nas vacinas. Ainda, são apontadas as razões para as diferentes taxas de cobertura e dificuldades observadas na implementação dos programas, considerando barreiras sociais e econômicas. Finalmente, são discutidos os principais determinantes de sucesso a longo prazo e estratégias para melhorar o acesso e a aderência aos programas de vacinação.

Descritores: Condiloma acuminado; Papillomaviridae; Vacinação em massa; Vacinas contra Papillomavirus; Avaliação do impacto na saúde; Neoplasias do colo do útero.

does not mount an immune response capable of preventing subsequent infections ${ }^{1}$.

HPVs are present in virtually all cases of cervical cancer and have also been linked with anogenital warts and precancerous lesions that can lead to head and neck, penile and anal cancers ${ }^{1,2,4,6}$. The incidence of these types of cancer is significant worldwide, but especially in less developed countries, where the prevalence of infection and lack of diagnosis and treatment are elevated ${ }^{1,7}$.
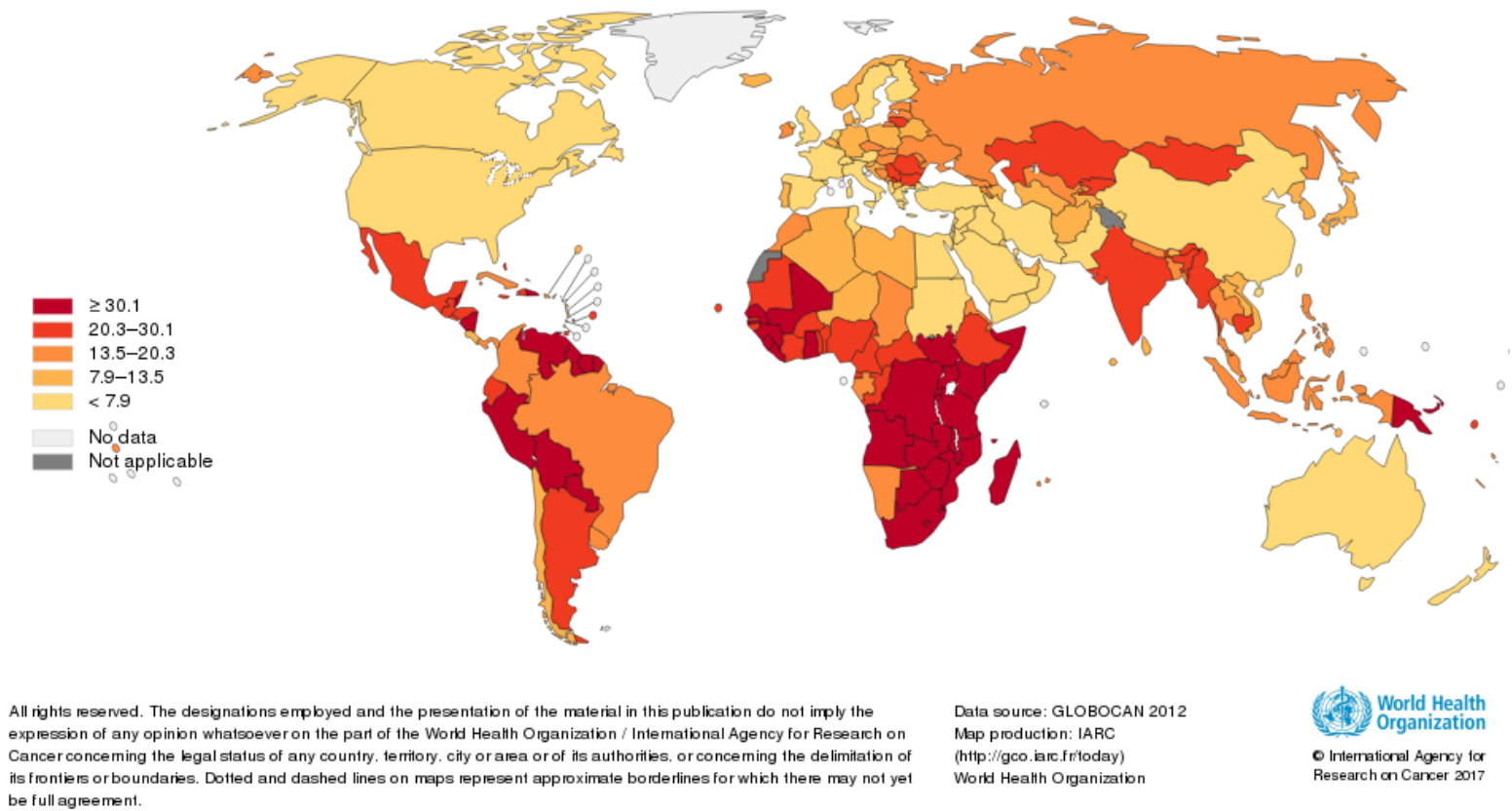

Data source: GLOBOCAN 2012

Map production: IARC

(hitp://gco.iarc.fritoday)

Word Heath Orgay)

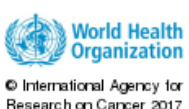

OInternational Agency tor its frontiers or bound

Figure 1. Global estimated age-standardized rates of incident cases of cervical cancer ${ }^{8}$

There are two main strategies for prevention of HPVrelated cancers: HPV vaccination (primary prevention) and screening (secondary prevention) ${ }^{9}$. There are currently three types of HPV vaccines available: types of HPV vaccines available: Cervarix ${ }^{\circledR}$, bivalent (HPV 16/18); Gardasil ${ }^{\circledR}$, quadrivalent (HPV 6/11/16/18); and Gardasil 9®), 
nonavalent (HPV 6/11/16/18/31/33/45/52/58) 7 . Prevention of cancer is more effective when HPV vaccination occurs before exposure to the virus ${ }^{10}$.

The bivalent vaccine prevents the acquisition of the virus types 16 and 18 , that are linked to $70 \%$ of the cervical cancer cases, also known as high risk types, and promotes limited cross protection against other genotypes ${ }^{6,10}$, as does the quadrivalent vaccine ${ }^{6}$. The HPV genotypes 6 and 11 are responsible for about $90 \%$ of all anogenital warts ${ }^{3,11}$ and are also linked with recurrent respiratory papillomatosis ${ }^{5}$. The infection with these last two genotypes is prevented by vaccination with quadrivalent and nonavalent HPV vaccines. The nonavalent vaccine is expected to increase the protection $^{6}$, covering the HPV types related to anogenital warts, recurrent respiratory papillomatosis and high-risk types infection that can lead to low- and high-grade cell abnormalities and cancer ${ }^{5}$.

An HPV vaccine was first introduced in a national immunization program in the end of $2006^{1,12}$. As of April 2017, about $40 \%$ of countries have introduced HPV vaccines in their national immunization programs, targeting mainly young females - teenage and infant girls between 9 and 13 years of age. As most cases of HPV-related cancer afflict women and there is evidence of herd immunity, males are usually excluded from these programs ${ }^{13}$. However, gender-neutral vaccination seems to be superior than female only, additionally promoting equity and equal access to healthcare ${ }^{3,6}$.

Few low and middle-income countries (LMICs) have implemented the HPV vaccine into their national immunization program due mostly to funding and cost of the vaccine, logistical and resource barriers, and cultural and political issues related to vaccination ${ }^{14}$.

Since the introduction of HPV vaccination in national immunization programs, numerous articles presenting data on its impact in real world have been published, supporting the effectiveness of an inclusive immunization program, preventing infection from spreading and demonstrating potential for reducing cancer incidence in both genders ${ }^{1,15}$. However, the vaccines available, the target groups and the coverage vary between - and within - countries in accordance to its population and economic characteristics. Moreover, the effectiveness of the vaccination programs is being measured differently throughout the world, analyzing outcomes such as incidence of genital warts and cervical lesions, as well as genotypes of HPV present in normal smears and lesions. These observations highlight the need of a critical analysis of the publications as to evaluate the results obtained by the HPV national vaccination programs in females as well as in the male population.

In 2014, Brazil implemented a wide HPV immunization program, initially aimed at 9 to 13 years old girls and recently expanded to young boys, besides especial groups such as transplanted and HIV-positive adults. After delivery of first dose, the program exhibited high coverage rates, surpassing the initial target of vaccinating $80 \%$ of girls in the established age range. However, from the second dose in 2014, indicators presented a sharp decrease, showing disappointing results in 2015 and 2016. This review describes the structure of Brazilian immunization program against HPV, including eligible groups, age ranges, schedules and coverage rates since 2014. The effectiveness of HPV vaccination in Brazil is still to be assessed, since it requires a longer period of evaluation, yet few studies evaluating practical outcomes are already in progress. Therefore, this article focuses on the main reasons for the low vaccine uptake observed countrywide and proposes feasible strategies to improve access and adherence to HPV vaccine. Finally, the key determinants of the long-term program success are briefly discussed.

\section{METHODS}

We performed a search of papers published from January 1st, 2011 until February 28th, 2017 in the databases PubMed, Scopus, Web of Science and Embase for data on HPV vaccination programs and its effectiveness using the keywords: HPV; vaccination; effectiveness; national immunization programs. We also searched the website of World Health Organization (WHO) and of countries' health organizations for additional information regarding immunization programs. The inclusion criteria were: publication in English: presentation or review of national immunization programs worldwide or real world effectiveness. The exclusion criteria were: mathematical modelling; clinical trials.

For the review on the Brazilian Immunization program, we additionally searched articles in SciELO with the keywords HPV, vaccine, immunization program, Brazil -, and retrieved information from the databases of the Brazilian Ministry of Health and the Information System of the National Immunization Program (SI-PNI) related to HPV vaccine coverage in 2014, 2015 and 2016, in order to analyze the campaign results. The criteria for inclusion were: systematic reviews, reviews and official data government, based on real world information. We excluded mathematical models and progressions, clinical trials, articles not in English or Portuguese language, and studies about HPV vaccine itself. Finally, we included articles evaluating factors involved in long-term program success and investigating the vaccination acceptance in specific cities of the country.

\section{National Immunization Programs Worldwide}

Cervical cancer is the fourth most common cancer among women and the seventh most common cancer overall. In 2012, approximately 527,624 women were diagnosed with cervical cancer and about $85 \%$ occurred in developing countries. Almost 9 in 10 cervical cancer 
Freitas ACGS, et al. Human papillomavirus vaccination in national immunization programs.

deaths occur in such regions ${ }^{16}$.

For decades, high-income countries have been able to implement high-coverage programs for screening and treatment of cervical precancer, which are based on regular Papanicolaou smears and appropriate treatment of precancerous lesions, along with treatment or palliative care for advanced cancer ${ }^{17}$. These have been reducing the disease incidence and mortality since the $1970 \mathrm{~s}^{18}$, but this expensive approach may prove difficult to implement and sustain in regions with low resources ${ }^{19,20}$ where screening and treatment programs are not fully available and mortality rate is still high.

More than 70 countries have introduced HPV vaccination in their National Immunization Programs, of which 30 are low- and middle-income countries ${ }^{21}$.
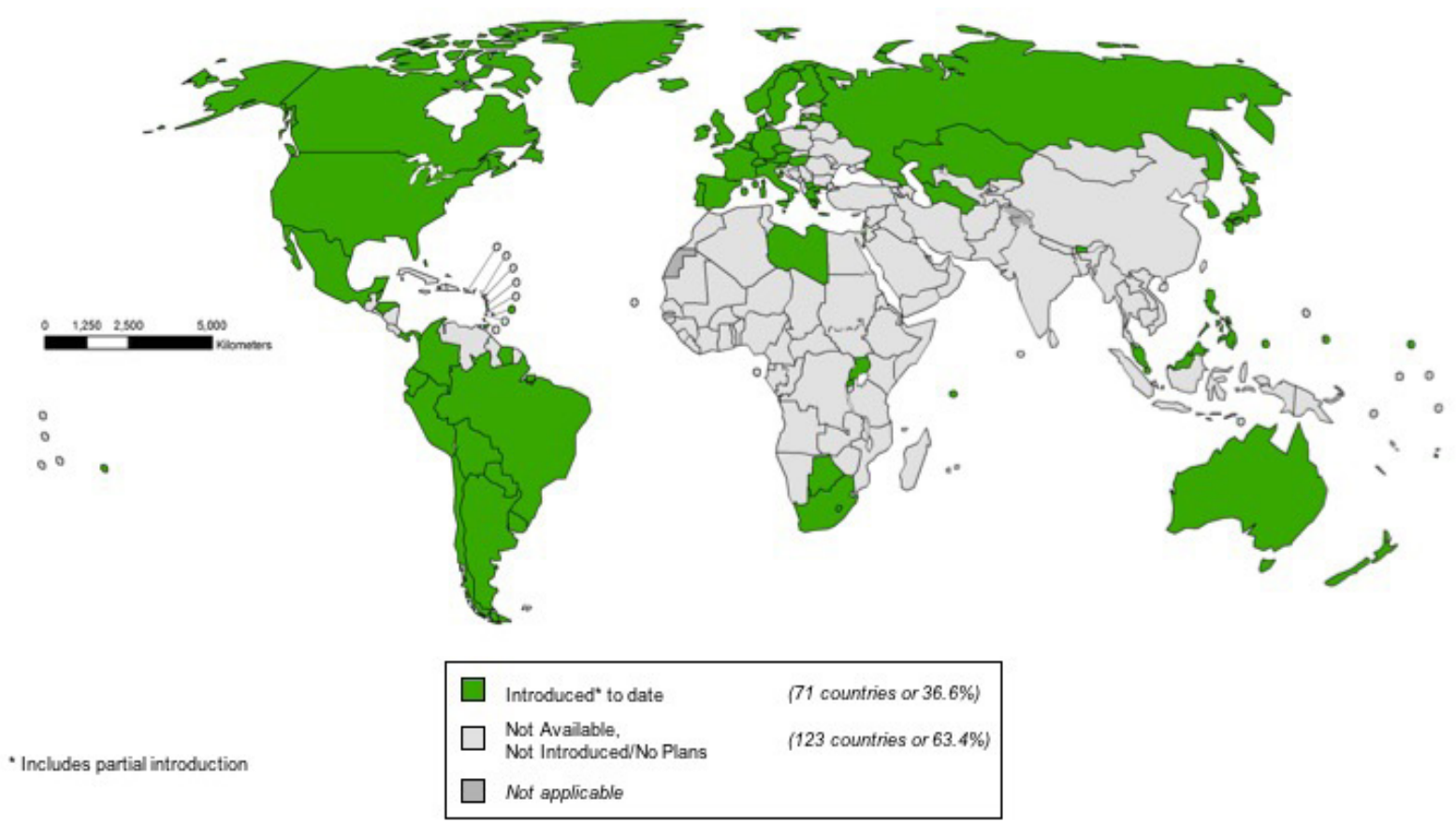

Data source: WHOIVB Database, as of 14 April 2017

Map production Immunization Vaccines and Biologicals (IVB)

Map production Immunization

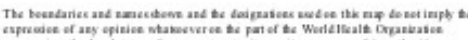

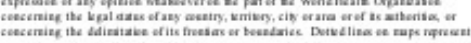

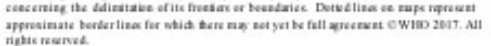

Figure 2. Countries with HPV vaccine in national immunization program in $2017^{21}$

After the first HPV vaccine was licensed in 2006, the first countries to introduce the HPV vaccine were the USA, Australia, Canada, and some European countries ${ }^{22}$. Panama in Latin America, Bhutan in Asia and Rwanda in Africa were the first LMICs that introduced HPV vaccination. Cost prevented the introduction of the vaccines into LMICs. Further impediments to the introduction of HPV vaccines included the challenges of the target age group and competing health priorities ${ }^{14}$.

\section{High income countries}

The United States, Australia, Canada and the United Kingdom (UK) were among the first countries to implement HPV vaccine into their national immunization programs. In Europe, the number of countries having introduced vaccine increased from 3 in 2007 to 28 in April 2017. While all country programs target young adolescent girls, specific target age groups vary. Different health care systems and infrastructure have resulted in varied implementation strategies.

\section{Low- and middle-income countries}

Within the first 10 years after vaccines became available, few LMICs had introduced HPV vaccine. The main reason was budgetary restrictions due to the high vaccine cost. Bhutan and Rwanda were the first lowincome countries to implement national immunization after receiving vaccine through donation programs in 2010 and 2011 , respectively ${ }^{23,24}$. Introduction of vaccine in LMICs requires a variety of factors and cooperation between international agencies and manufacturers ${ }^{25}$.

In most programs, a school-based approach is predominantly used to deliver the vaccine to the target adolescents with additional efforts using field clinics, and primary health centers to cover girls who missed vaccination and do not attend schools. 
Freitas ACGS, et al. Human papillomavirus vaccination in national immunization programs.

Implementation's Barriers for HPV Vaccination and Main Financing Mechanisms for LMICs

Significant progress has been made to improve the affordability of HPV vaccine to LMICs through financing mechanisms, including GAVI, the Vaccine Alliance, and the Pan American Health Organization (PAHO) Revolving Fund.

The Global Alliance for Vaccines and Immunizations (GAVI) was created in 2000 to support the implementation of vaccination programs to reduce child mortality rates in the world's poorest countries through funds from donors worldwide, and decides which vaccines would be the most efficacious and cost-effective to introduce to these countries ${ }^{26}$. Although the GAVI Alliance prioritized the HPV vaccine in 2009, it was not until 2012 that both HPV vaccines were first made available to GAVIeligible countries, thanks in part to tiered pricing by the manufacturers, which dramatically reduced the cost of each dose, that is now available for the poorest countries for U\$4.50 per dose ${ }^{27}$. GAVI may cover the costs for vaccines and some logistical costs, but the states are responsible for the delivery. Introduction of vaccine requires capacity for storage, transport, and personnel, which might be lacking in the country, further complicating the launch of the vaccine program. Due to infrastructure and capacity issues, many GAVI countries may delay the introduction of this vaccine ${ }^{28}$.

The PAHO Revolving Fund was established in 1977 as a mechanism for procurement of supplies and equipment necessary for sustained delivery of vaccines. By buying in bulk, the Fund greatly improves its purchasing power $^{29}$. Through this mechanism, a price of US $\$ 9.80$ for the quadrivalent and U\$8.50 for the bivalent vaccine per dose has been recently achieved ${ }^{30}$.

Nowadays, $80 \%$ girls aged 9-13 years in the Latin American region have access to HPV vaccination through national immunization programs due to political will and the negotiated purchase of the vaccines ${ }^{31}$.

Table 1 summarizes the information on HPV vaccination in main countries in different regions of the world. The unavailability of updated information in government official websites and health organizations was the leading difficulty faced in data gathering. This review article does not have the pretension to update on HPV national immunization programs in all countries but to provide an overview and illustrate the difference between the HPV vaccine offered through national programs in high income countries and low-middle income countries.

Table 1. National HPV Immunization Programs Worldwide

\begin{tabular}{|c|c|c|c|c|c|c|c|}
\hline Country & $\begin{array}{c}\text { Year of } \\
\text { introduction }\end{array}$ & Gender & $\begin{array}{l}\text { Primary target } \\
\text { age group }\end{array}$ & Delivery strategy & Dosage & Vaccine & References \\
\hline \multicolumn{8}{|l|}{ Americas } \\
\hline Argentina & 2011 & $\mathrm{~F} \& \mathrm{M}$ & 11 & Health Center & 2 & $2 \mathrm{v}$ & 32 \\
\hline Brazil & 2014 & $\mathrm{~F} \& \mathrm{M}$ & 9-13 F; 12-13 M & School and Health Center & 2 & $4 \mathrm{v}$ & 33 \\
\hline Canada & 2007-2009 & $\mathrm{F} \& \mathrm{M}$ & $9-14$ & School & 2 & $2 \mathrm{v} ; 4 \mathrm{v}$ & 34 \\
\hline Chile & 2014 & $\mathrm{~F}$ & 9 & School & 2 & $4 \mathrm{v}$ & 35 \\
\hline Colombia & 2012 & $\mathrm{~F}$ & $9-17$ & $\begin{array}{l}\text { School and specials } \\
\text { campaigns }\end{array}$ & 2 & $4 \mathrm{v}$ & 36 \\
\hline Mexico & 2012 & $\mathrm{~F}$ & $9-11$ & School and Health Center & 2 & - & 37 \\
\hline Paraguay & 2013 & $\mathrm{~F}$ & 12 & School & 3 & $4 \mathrm{v}$ & 38 \\
\hline Panama & 2008 & $\mathrm{~F} \& \mathrm{M}$ & 10 & School and Health Center & 2 & $4 \mathrm{~V}$ & 39 \\
\hline Peru & 2011 & $\mathrm{~F}$ & $9-13$ & School & 2 & $4 \mathrm{v}$ & 40 \\
\hline $\begin{array}{l}\text { United } \\
\text { States }\end{array}$ & 2006 & $\mathrm{~F} \& \mathrm{M}$ & $11-12$ & Health Center & 2 & $9 \mathrm{v}$ & 41 \\
\hline Uruguay & 2013 & $\mathrm{~F}$ & 12 & Health Center & 3 & $4 v$ & 42 \\
\hline \multicolumn{8}{|l|}{ Europe } \\
\hline Austria & 2014 & $\mathrm{~F} \& \mathrm{M}$ & $9-12$ & School & 2 & $9 \mathrm{v}$ & 43 \\
\hline Denmark & 2009 & $\mathrm{~F}$ & $12-18$ & Health Center & 2 & $2 \mathrm{v}$ & 44 \\
\hline France & 2007 & $\mathrm{~F}$ & $11-14$ & Health Center & 2 & $2 \mathrm{v} ; 4 \mathrm{v}$ & 45 \\
\hline Germany & 2007 & $\mathrm{~F}$ & $9-14$ & Health Center & 2 & $2 \mathrm{v} ; 4 \mathrm{v} ; 9 \mathrm{v}$ & 46 \\
\hline Ireland & 2010 & $\mathrm{~F}$ & $13-14$ & School & 2 & $4 v$ & 47 \\
\hline Portugal & 2008 & $\mathrm{~F}$ & 10 & Health Center & 2 & $9 \mathrm{v}$ & 48 \\
\hline
\end{tabular}


Freitas ACGS, et al. Human papillomavirus vaccination in national immunization programs.

Table 1. National HPV Immunization Programs Worldwide

Continuation

\begin{tabular}{|c|c|c|c|c|c|c|c|}
\hline Country & $\begin{array}{c}\text { Year of } \\
\text { introduction }\end{array}$ & Gender & $\begin{array}{l}\text { Primary target } \\
\text { age group }\end{array}$ & Delivery strategy & Dosage & Vaccine & References \\
\hline $\begin{array}{l}\text { United } \\
\text { Kingdom }\end{array}$ & 2008 & $\mathrm{~F}$ & $12-13$ & School & 2 & $4 v$ & 49 \\
\hline \multicolumn{8}{|c|}{ Western Pacific } \\
\hline Australia & 2007 & $\mathrm{~F} \& \mathrm{M}$ & $12-13$ & School & 3 & $4 \mathrm{v}$ & 50 \\
\hline Malaysia & 2010 & $\mathrm{~F}$ & 13 & School and Health Center & 2 & - & 51,52 \\
\hline $\begin{array}{l}\text { New } \\
\text { Zealand }\end{array}$ & 2008 & $\mathrm{~F} \& \mathrm{M}$ & $9-26$ & School and Health Center & 2 & $9 \mathrm{v}$ & 53 \\
\hline \multicolumn{8}{|l|}{ Africa } \\
\hline Angola & 2015 & $\mathrm{~F}$ & $10-14$ & Health Center & 3 & - & 54 \\
\hline Rwanda & 2011 & $\mathrm{~F}$ & $11-12$ & School & 2 & - & 51,52 \\
\hline South Africa & 2014 & $\mathrm{~F}$ & 9 & School & 2 & $4 \mathrm{v}$ & 51,52 \\
\hline \multicolumn{8}{|l|}{ South Asia } \\
\hline Bhutan & 2010 & $\mathrm{~F}$ & 12 & School and Health Center & 3 & $4 \mathrm{v}$ & 23 \\
\hline
\end{tabular}

\section{Impact and effectiveness of HPV vaccination as a public} health policy

A total of 19 articles were included in the review of vaccination programs' impact and effectiveness, all conducted in high-income countries.

\section{HPV genotypes}

As mentioned before, the bivalent vaccine (HPV $16 / 18$ ) offers protection against infection with high risk types, while the quadrivalent vaccine (HPV 6/11/16/18) also protects against the genotypes responsible for most anogenital warts and respiratory papillomatosis.

In Belgium, after testing cervical cell samples for HPV genotyping, it was found that the risk of infection with HPV vaccine types was significantly lower for vaccinated women aged 18-29 years, except for infection with HPV 11 , and there was a higher risk of infection with other high-risk HPV types ${ }^{55}$.

The United Kingdom introduced the bivalent HPV vaccine in 2008, switching to the quadrivalent in 2012; however, the articles included in this review are from the period of the bivalent vaccine ${ }^{56-59}$. In Scotland, a reduced prevalence in HPV 16 and 18 was reported, specially among women who received all three vaccine doses, with cross-protection against HPV 31, 33 and $45^{58}$. The annual prevalence of HPV 16/18 in cervical cell samples decreased with each year since vaccine introduction among vaccinated women, with an HPV 16 and 18 prevalence even lower in younger women, in those who had received more doses of the vaccine ${ }^{57}$. Similar results occurred in England, pronouncedly in the 16-18 and 19-21 years age groups ${ }^{56}$. National data from all countries in United Kingdom confirms a decreased prevalence in HPV 16/18, markedly in women between 16 and 18 years of age, with similar results for other HPV genotypes in comparison with previous studies ${ }^{59}$. Women from less deprived areas and those who were vaccinated at a younger age also had lower odds of infection with these HPV genotypes ${ }^{57}$. There was also evidence of cross-protection for HPV $31^{56}$ and for HPV 31, 33 and $45^{57}$, and of herd immunity for unvaccinated women ${ }^{56,57}$.

The Australian HPV vaccination program used the quadrivalent vaccine since its start in 2007, vaccinating young women between 10 and 26 years of age ${ }^{60}$. An overall decrease in HPV prevalence was observed, with greater differences in the vaccine-targeted HPV genotypes, even amongst unvaccinated women ${ }^{60}$. In the post-vaccination period of observation, infection with vaccine-targeted HPV types was highest among the unvaccinated women and lowest in the fully vaccinated group ${ }^{60}$.

A different approach, in the United States of America, revealed significant declines in CIN2+ and CIN 3+ lesions attributable to HPV-16/18 in women who received at least one quadrivalent vaccine dose within 6 years from the start of the vaccination program ${ }^{12}$.

\section{Genital and anal warts}

Anogenital warts are important short term indicators of impact and effectiveness of HPV vaccination programs, since the median development time for these lesions is around 3 months after infection with HPV types 6 and 11 , whilst the development of cervical cancer occurs over several years or decades ${ }^{4,11}$. Only the quadrivalent and nonavalent vaccines offer protection against HPV 6 and 11 and, in this case, only data on the quadrivalent vaccine was recovered.

A total of 4 studies focused on genital warts' incidence in both genders ${ }^{3,4,61,62}$; another measured the incidence of anogenital warts in both men and women ${ }^{11}$. The results of vaccination over men reflect herd immunity, since only women were vaccinated in the considered period. 
An additional study was conducted in Canada, with girls before and after vaccine exposure, calculating absolute and relative risks of developing cervical dysplasia and anogenital warts, with an apparent reduction in the latter ${ }^{63}$; however, the authors deemed these last results imprecise. In all other cases, the authors were able to ascertain that the results were most likely due to HPV vaccination and not to possible behavioral changes by assessing the incidence of Chlamydia infections ${ }^{3,4,11,61,62}$ and other sexually transmitted diseases $^{61}$, as a proxy for behavior.

In Denmark, a significant decrease in anogenital warts was observed among 15- to 24-year-old men and women ${ }^{11}$. After a second catch-up program was instituted for women up to 27 years, progressive smaller reductions were observed in women aged 20-35 and in men aged 2029 , with no significant change in genital warts incidence for women aged 36 or older and for men aged 30 years or older ${ }^{3}$.

Similar results were reported in Belgium, with an overall $8.1 \%$ reduction on the incidence of genital warts in men and women with ages between $18-59$ years $^{4}$. The quadrivalent vaccine was most effective when all three doses were administered, with significant decreases even after one or two doses and higher effectiveness when women were vaccinated at a younger age (before completing 18 years), when prior exposure to HPV is less likely ${ }^{4}$.

In Australia, an overall reduction of $59 \%$ in genital warts incidence in women was observed, though no significant decrease was found in females that were not eligible for free vaccination ${ }^{61}$. In heterosexual men, there was a $28 \%$ decrease in total, but no significant change in older ages and in men who have sex with men (MSM) ${ }^{61}$. A subsequent study identified decreases of up to $92.6 \%$ in genital warts in women aged up 30 years, but no significant decline in older women ${ }^{62}$. There were no diagnosed genital warts in vaccinated women under the age 21 in 2011 and less than $1 \%$ of women who were 21 years old or younger in that year were found to have genital warts, against $10.5 \%$ in 2006 (pre-vaccination) ${ }^{62}$. In heterosexual men, a similar pattern was observed, with up to $81.8 \%$ decline in men aged up to 30 years, but no significant changes in those of 30 years or older, while in MSM, a lower overall decline of $24.7 \%$ was observed ${ }^{62}$.

Table 2. Impact of HPV vaccination on anogenital warts in men and women

\begin{tabular}{|c|c|c|c|c|c|c|c|}
\hline Country & Author & $\begin{array}{l}\text { Years since } \\
\text { vaccine } \\
\text { introduction }\end{array}$ & $\begin{array}{l}\text { Vaccine } \\
\text { available }\end{array}$ & Target group & $\begin{array}{l}\text { Coverage } \\
\text { rate }\end{array}$ & $\begin{array}{l}\text { Incidence rate } \\
\text { after vaccination } \\
\text { (women) }\end{array}$ & $\begin{array}{l}\text { Incidence rate after vaccination } \\
\text { (men) }\end{array}$ \\
\hline Denmark & $\begin{array}{l}\text { Sando et } \\
\text { al. } .^{11}\end{array}$ & within 3 & $\begin{array}{l}\text { quadrivalent; } \\
\text { free }\end{array}$ & $\begin{array}{l}12 \text { years old } \\
\text { girls; catch up } \\
\text { at age } 16\end{array}$ & $\begin{array}{l}80 \% \text { all } \\
\text { doses } \\
90 \% \text { first } \\
\text { dose }\end{array}$ & $\begin{array}{l}\text { aged } 15-19:-67 \% \\
\text { aged } 20-24:-18 \% \\
\text { aged } 25-29:+11 \% \\
\text { aged } 30-34: \text { no } \\
\text { significant changes }\end{array}$ & $\begin{array}{l}\text { aged } 15-19:-50 \% \\
\text { aged } 20-24:-6 \% \\
\text { aged } 25-29: \text { no significant } \\
\text { changes } \\
\text { aged } 30-34:+13 \%\end{array}$ \\
\hline Denmark & $\begin{array}{l}\text { Bollerup et } \\
\text { al. }{ }^{3}\end{array}$ & within 5 & $\begin{array}{l}\text { quadrivalent; } \\
\text { free }\end{array}$ & $\begin{array}{l}12 \text { years old } \\
\text { girls; catch up } \\
\text { at age } 15 \text { up } \\
\text { to } 2010 \text { and at } \\
\text { age } 27 \text { from } \\
2012 \text { on }\end{array}$ & $\begin{array}{l}87-91 \% \text { at } \\
\text { least one } \\
\text { dose } \\
(75 \% \text { in } \\
\text { the second } \\
\text { catch-up } \\
\text { program) }\end{array}$ & $\begin{array}{l}\text { aged } 12-15:-42.7 \% \\
\text { aged } 16-17:-55.1 \% \\
\text { aged } 18-19:-39.0 \% \\
\text { aged } 20-21:-20.9 \% \\
\text { aged } 22-25:-11.7 \% \\
\text { aged } 26-29:-5.5 \% \\
\text { aged } 30-35:-3.7 \% \\
\text { aged } 36+:+0.4 \%\end{array}$ & $\begin{array}{l}\text { aged } 12-15:-24.5 \% \\
\text { aged } 16-17:-36.7 \% \\
\text { aged } 18-19:-34.4 \% \\
\text { aged } 20-21:-21.0 \% \\
\text { aged } 22-25:-8.8 \% \\
\text { aged } 26-29:-3.1 \% \\
\text { aged } 30-35:-0.8 \% \\
\text { aged } 36+:+2.1 \%\end{array}$ \\
\hline Belgium & $\begin{array}{l}\text { Dominiak- } \\
\text { Felden et } \\
\text { al. }{ }^{4}\end{array}$ & within 6 & $\begin{array}{l}\text { quadrivalent; } \\
\text { reimbursement }\end{array}$ & $\begin{array}{l}12 \text { to } 18 \text { years } \\
\text { old females }\end{array}$ & $43 \%$ & $\begin{array}{l}\text { aged } 18-59 \\
\text { (considering both } \\
\text { sexes): }-8.1 \% \\
\text { aged } 16-22:-72.1 \% \\
\text { aged } 23-30:-18.8 \% \\
\text { aged } 31-40:+20.0 \% \\
\text { aged } 41-59:+33.1 \%\end{array}$ & $\begin{array}{l}\text { aged } 18-59(\text { considering both } \\
\text { sexes): }-8.1 \% \\
\text { aged } 16-22:-51.1 \% \\
\text { aged } 23-30:+14.2 \% \\
\text { aged } 31-40:+10.2 \% \\
\text { aged } 41-59:+27.3 \%\end{array}$ \\
\hline Australia & $\begin{array}{l}\text { Donovan et } \\
\text { al. }{ }^{61}\end{array}$ & within 3 & $\begin{array}{l}\text { quadrivalent; } \\
\text { free }\end{array}$ & $\begin{array}{l}12 \text { years old } \\
\text { girls; catch-up } \\
\text { up to the age } \\
\text { of } 26 \text { years }\end{array}$ & $\begin{array}{l}80 \% \text { first } \\
\text { dose } \\
70 \% \text { three- } \\
\text { dose }\end{array}$ & $\begin{array}{l}\text { overall: }-59 \% \\
\text { aged } 26+: \text { not } \\
\text { significant }\end{array}$ & $\begin{array}{l}\text { heterosexual overall: - } 28 \% \\
\text { heterosexual, aged } 12-26 \text { years: } \\
\text { - } 39 \% \\
\text { heterosexual, aged } 26+\text { years: not } \\
\text { significant } \\
\text { MSM: not significant }\end{array}$ \\
\hline Australia & Ali et al. ${ }^{62}$ & within 5 & $\begin{array}{l}\text { quadrivalent; } \\
\text { free }\end{array}$ & $\begin{array}{l}\text { girls aged } \\
12-13 \text {; } \\
\text { catch-up for } \\
13-18 \text {-year- } \\
\text { old } \\
\text { schoolgirls } \\
\text { and } \\
18-26 \text {-year- } \\
\text { old women } \\
\text { in the } \\
\text { community }\end{array}$ & $\begin{array}{l}83 \% \text { first } \\
\text { dose } \\
80 \% \\
\text { second } \\
\text { dose } \\
73 \% \text { third } \\
\text { dose }\end{array}$ & $\begin{array}{l}\text { aged up to } 21 \text { years: } \\
92.6 \% \\
\text { aged } 21-30 \text { years: } \\
72.6 \% \\
\text { aged } 30+: \text { no } \\
\text { significant decline }\end{array}$ & $\begin{array}{l}\text { heterosexual, aged up to } 21 \\
\text { years: }-81.8 \% \\
\text { heterosexual, aged } 21-30 \text { years: } \\
-51.1 \% \\
\text { heterosexual, aged } 30+: \text { no } \\
\text { significant decline } \\
\text { MSM: }-24.7 \%\end{array}$ \\
\hline
\end{tabular}


Freitas ACGS, et al. Human papillomavirus vaccination in national immunization programs.

\section{Cervical cell abnormalities}

Since cervical cancer develops over the course of years or decades, vaccination impact over cancer rates were still not observed. However, it is possible to assess the vaccination impact over low- and high-grade cervical intraepithelial neoplasia (CIN) and squamous intraepithelial lesions (LSILs and HSILs). Both the bivalent and quadrivalent vaccines, addopted by most countries to date, offer protection against HPV 16 and 18, linked with most cases of cervical lesions.

Three doses of the bivalent vaccine lowered the incidence of CIN3 and the risk of diagnoses of CIN2 and CIN1, but no statistically significant decline in incidence was reported with partial immunization in Scotland ${ }^{64}$, whilst in Australia it was found that receiving any number of vaccine doses led to lower rates of histologically confirmed high-grade cervical abnormalities and lower rates of highgrade and low-grade cytology diagnoses ${ }^{65}$.

A decreased incidence in CIN2+ was observed in 18 to 20 years old women in USA, but not in older group ages $^{66}$. However, it could not be ascertained whether this

Table 3. Impact of HPV vaccination on cervical cell abnormalities

\begin{tabular}{|c|c|c|c|c|c|c|}
\hline Country & Author & $\begin{array}{l}\text { Years since } \\
\text { program } \\
\text { introduction }\end{array}$ & $\begin{array}{l}\text { Vaccine } \\
\text { available }\end{array}$ & Target group & Coverage rate & Results (women only) \\
\hline Scotland & $\begin{array}{l}\text { Pollock et } \\
\text { al. }{ }^{64}\end{array}$ & within 4 & $\begin{array}{l}\text { Bivalent and } \\
\text { quadrivalent; } \\
\text { free }\end{array}$ & $\begin{array}{l}12 \text { - to } 13 \text {-year- } \\
\text { old girls; } \\
\text { catch-up up to } \\
18 \text { years of age }\end{array}$ & over $90 \%$ & $\begin{array}{l}\text { Age group: } 20-21 \text { years, three-doses } \\
\text { CIN 1: RR } 0.71 \\
\text { CIN 2: RR } 0.5 \\
\text { CIN 3: RR } 0.45\end{array}$ \\
\hline Australia & $\begin{array}{l}\text { Brotherton } \\
\text { et al. }{ }^{65}\end{array}$ & within 4 & $\begin{array}{l}\text { Quadrivalent; } \\
\text { free }\end{array}$ & Not described & over $50 \%$ & $\begin{array}{l}\text { Any number of doses }(1,2 \text { or } 3) \text { : lower rates of } \\
\text { high grade and low grade cytology diagnoses } \\
\text { and outcomes if doses given before screening } \\
\text { commencement }\end{array}$ \\
\hline USA & $\begin{array}{l}\text { Hariri et } \\
\text { al. }^{66}\end{array}$ & within 5 & $\begin{array}{l}\text { Bivalent and } \\
\text { quadrivalent; } \\
\text { varies with State }\end{array}$ & Women & $11.6-34.5 \%$ & $\begin{array}{l}\text { Age group: } 18-20 \text { years } \\
\text { CIN2+: Ptrend }<.0001 \\
\text { Age group: } 21-29 \text { years } \\
\text { CIN2+: Ptrend }<.001 \\
\text { Age group: } 30 \text { - to } 39 \text {-year-olds } \\
\text { CIN2+: no significant difference } \\
\text { *vaccination contribution not quantifiable }\end{array}$ \\
\hline Sweden & $\begin{array}{l}\text { Herweijer } \\
\text { et al. }{ }^{67}\end{array}$ & within 6 & $\begin{array}{l}\text { Quadrivalent; } \\
\text { reimbursement } \\
(2007-2011) ; \\
\text { free (2012) }\end{array}$ & $\begin{array}{l}\text { Girls aged } \\
13-17 \text { years } \\
(2007-2011) \\
\text { girls aged } 10- \\
12 \text { years, with } \\
\text { catch-up doses } \\
\text { at } 13-18 \text { years } \\
\text { (from } 2012 \text { on) }\end{array}$ & $\begin{array}{l}\text { First-dose: } \\
82 \% \text { (target } \\
\text { group); } 60 \% \\
\text { (catch-up and } \\
\text { subsidized } \\
\text { vaccinations) } \\
(2014)\end{array}$ & $\begin{array}{l}\text { Age at vaccination: up to } 17 \text { years } \\
\text { CIN2+: VE } 75 \% \text {, IRR } 0.25 \\
\text { CIN3+: VE } 84 \% \text {, IRR } 0.16 \\
\text { Age at vaccination: } 17-20 \text { years } \\
\text { CIN2+: VE } 46 \% \text {, IRR } 0.54 \\
\text { CIN3+: VE } 57 \% \text {, IRR } 0.43 \\
\text { Age at vaccination: } 20-29 \text { years } \\
\text { CIN2+: VE } 22 \% \text {, IRR } 0.78 \\
\text { CIN3+: VE } 25 \% \text {, IRR } 0.75\end{array}$ \\
\hline Canada & $\begin{array}{l}\text { Mahmud } \\
\text { et al. }{ }^{68}\end{array}$ & within 4 & $\begin{array}{l}\text { Quadrivalent; } \\
\text { free }\end{array}$ & Girls & Not mentioned & $\begin{array}{l}\text { Age group: } 15-17 \text { years } \\
\text { HSILs: VE } 35 \% \\
\text { LSILs: VE } 21 \% \\
\text { ASCUS: }-1 \% \\
\text { Risk reduction for LSL: } 24 \% \\
\text { Age group: } 18 \text { or older } \\
\text { Significance varied with previous lesions and tests }\end{array}$ \\
\hline Canada & $\begin{array}{l}\text { Ogilvie et } \\
\text { al. }{ }^{69}\end{array}$ & within 4 & $\begin{array}{l}\text { Quadrivalent; } \\
\text { free }\end{array}$ & $\begin{array}{l}\text { Pre-adolescent } \\
\text { girls; catch-up } \\
\text { for adolescents } \\
\text { girls }\end{array}$ & $58-62 \%$ & $\begin{array}{l}\text { Age group: } 15-17 \text { years (vaccinated) } \\
\text { CIN2+: IRR from } 0.91 \text { to } 0.36 \\
\text { Age group: } 18-22 \text { years (unvaccinated) } \\
\text { CIN2+: IRR from } 0.95 \text { to } 0.99\end{array}$ \\
\hline Canada & $\begin{array}{l}\text { Smith et } \\
\text { al. }^{63}\end{array}$ & within 5 & $\begin{array}{l}\text { Quadrivalent; } \\
\text { free }\end{array}$ & $\begin{array}{l}\text { Girls aged 9-13 } \\
\text { years }\end{array}$ & $\sim 50 \%$ & $\begin{array}{l}\text { Age group: } 14-17 \text { years } \\
\text { Incidence of dysplasia: }-5.70 / 1000 \text { girls } \\
\text { Relative reduction: } 44 \% \text { (RR } 0.56 \text { ) }\end{array}$ \\
\hline
\end{tabular}

reduced incidence was due to vaccination, reflecting the difficulties of this assessment in the USA ${ }^{66}$.

In Sweden, there was evidence of effectiveness of vaccination over CIN2+ and CIN $3+$, with lower incidence rates in vaccinated females after three doses of the quadrivalent vaccine were administered, more evidently when vacciantion occurred at younger ages (up to 17 years $)^{67}$.

Three different studies from Canada assessing HPV vaccine effectiveness over cervical lesions were included in this review. The first, conducted in Manitoba, found moderate effectiveness over prevention of SILs among 1517 year old girls, but lower for other types of lesions (SILs and atypical squamous cells of undetermined significance - ASCUS) and for other age groups, especially when there was a history of abnormal cytology ${ }^{6}$. In British Columbia, a significant decrease in CIN2 and CIN2+ was observed in vaccinated 15-17-year-old girls, but not in unvaccinated 18-22-year-old women ${ }^{69}$. Finally, in Ontario, data reflected reduced dysplasia incidence in vaccinated girls aged 14 to 17 years $^{63}$. 


\section{Vaccination effectiveness}

Different methodologies were used to assess the impact and the effectiveness of HPV vaccination in the reviewed studies, which is a challenge for comparing and consolidating the obtained results. It was not the objective of this review to compare or validate these approaches, but to report the main trends. A meta-analysis is recommended to enable further conclusions.

A significant reduction in the monitored outcome after vaccination was observed in all studies for at least one subgroup (according to age, sex and sexual orientation), which points to the positive impact of HPV vaccination in real-world settings, reducing infection with various HPV genotypes and the incidence of lesions, such as anogenital warts and neoplasia, mainly in vaccinated subjects but also in some unvaccinated populations. Thus, herd protection has been observed, prominently in heterosexual men of age groups close to the vaccinated subjects ${ }^{4}$, with an accentuated effect with higher coverage and expanded target groups. The impact and effectiveness of HPV vaccination seems to be higher when the vaccine is administered at a younger age, before sexual debut and exposure to HPV infection ${ }^{63,65-68}$.

In the light of these findings, all within 6 years since the onset of the vaccination programs, it can be reasonably expected to observe further decreases in the incidence of HPV-related lesions and neoplasias, with the aging of the vaccinated population and the reduced circulation of the virus due to the herd immunity effect. Moreover, these results herald future reductions in the incidence of HPVrelated cancer as the final effect of the HPV vaccination, considering the aging of vaccinated population and the time frame (due to latency and repeated infections) of the development of cancer ${ }^{1,11,70}$.

Further studies reflecting data gathered after the inclusion of more groups in vaccination programs, such as boys and immunosuppressed patients, will reveal the impact of the strategy over these target groups and the overall population. Also, the real-world impact of vaccination over other HPV-related lesions still requires more information, specially among men.

HPV vaccination is also expected to have an impact over screening methods, with the shift from the prevalent cytology (alone or with HPV co-testing) to HPV testing, since cervical cancer is expected to have a reduced prevalence in the future ${ }^{2,70}$. Novel policies must be considered when higher coverage and longer vaccination period are attained ${ }^{2}$. We expect to see significant changes in screening algorithms in the years to come.

\section{The Brazilian Immunization Program against HPV}

\section{Program Operation and Vaccination Coverage}

In Brazil, cervical cancer is the third most common neoplasia among women (excluding non-melanoma skin cancer $)^{71}$ and represents the fourth cause of cancer death in Brazilian women, being responsible for 5.448 deaths in $2014^{72}$. HPV infection in Brazilian women with normal cervical cytology varies between $10.4 \%$ and $24.5 \%{ }^{73}$. In order to fight cervical cancer using a primary prevention strategy, the Brazilian Ministry of Health announced that the Unified Health System (SUS) would incorporate the vaccination against HPV from March 2014.

Initially, the target population would be girls at ages 9-13 years, who would receive free of charge the quadrivalent vaccine (against HPV types 6, 11, 16 and 18) by stages: in 2014, vaccine would be delivered to girls aged 11-13 years old; in 2015, to girls aged 9 -11; and from 2016 on, to nine years old girls. The goal was to vaccinate $80 \%$ of the cohort, roughly 4.2 million girls in $2014,4.2$ million in 2015 and 1.3 million in 2016. Administration of the three doses would occur under the permission of parents or guardians of pre-adolescents according to the extended schedule. In order to improve vaccine access, the first stage of HPV immunization program took place at public and private schools and primary care clinics (Unidades Básicas de Saúde - UBSs) ${ }^{74}$.

The campaign was highly successful during the first phase, in 2014. According to the Information System of the National Immunization Program (SI-PNI), the first dose of the vaccine was given to 4,847,356 girls in the age group of 11 to 13 years, reaching a higher coverage than initially targeted. In the same year, however, coverage of the second dose was significantly lower (40.8\%). This trend continues to be observed for girls between 9 and 13 years: in 2015 , the first dose was delivered to only $41.1 \%$ of the younger girls and $22.5 \%$ of them received the second dose. Between January and October 2016, only $12 \%$ of girls between the ages of 9 and 13 received the first dose and, at the same time, around $8.7 \%$ were immunized with the second dose. Doses applied in previous years from the State of Amazonas and the Brazilian Federal Capital District and from some municipalities that had implemented the HPV vaccine before March 2014 are not being computed ${ }^{75}$ (Figure 3 ).

In 2016, the Brazilian Ministry of Health decided to reduce from 3 to 2 doses the vaccination schedule (except girls and women living with HIV) based on evidence that antibody responses in girls were non-inferior after 2 doses compared to 3 doses $^{76}$ and to include 14 years-old girls who had not taken one or two doses previously, about 500,000 more girls. Due to such changes, the amount of vaccines available allowed the inclusion of boys in the program. In 2017, nearly 3.6 million of boys aged at 12-13 were offered the quadrivalent HPV vaccine in two doses, with a 6 months interval between doses. Furthermore, about 99,500 HIV-positive boys and men aged 9-26 years will also be immunized, under 3-doses schedule (2 and 6 months intervals after the first dose). In 2018, target population will be boys aged 11-12; in 2019, those aged 10-11; and from 2020, those aged 9-10 (Table 4). 


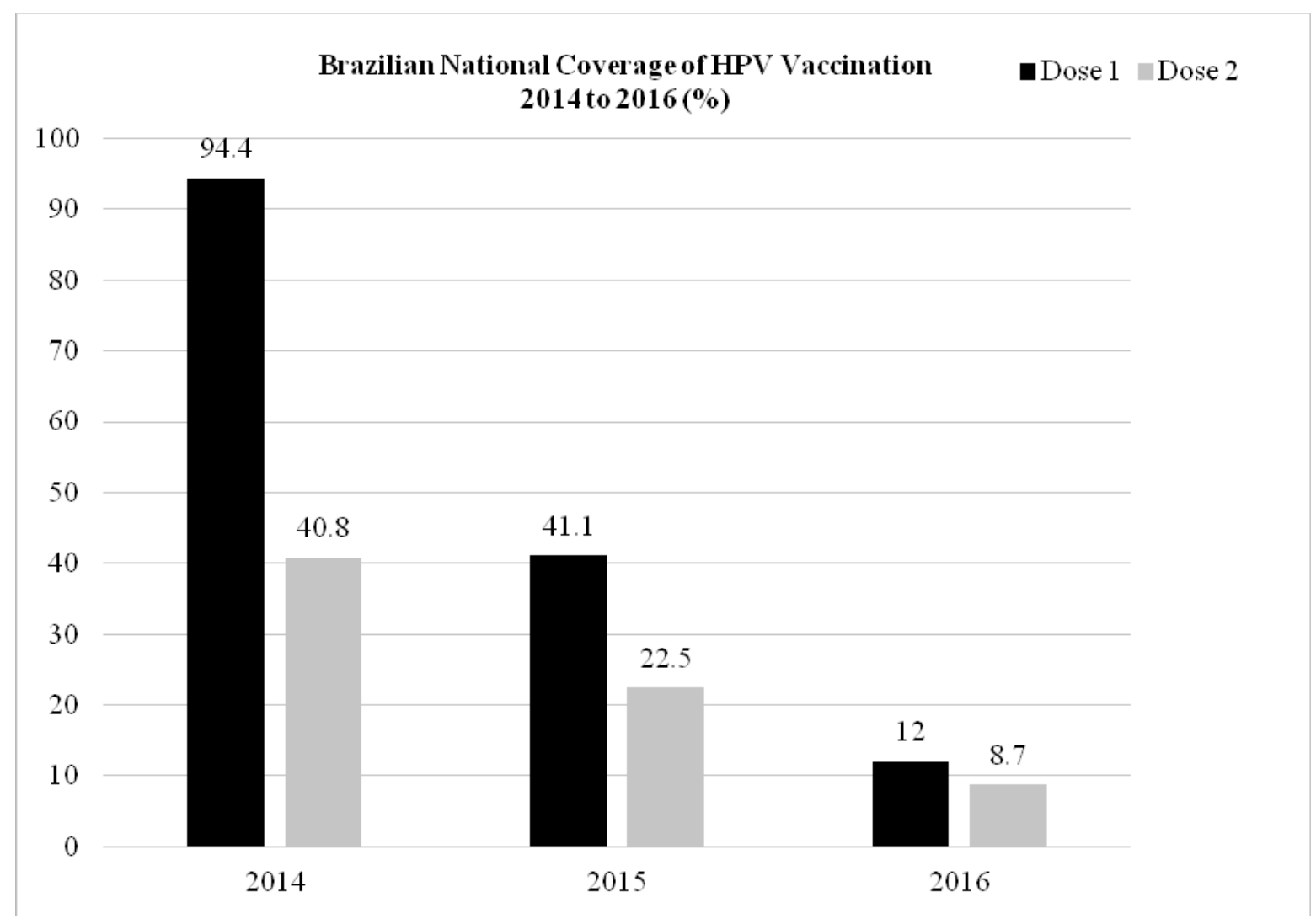

Figure 3. Brazilian National Coverage of HPV vaccination: 2014 to $2016^{75}$

Table 4. Eligible Population to Receive Free HPV Vaccination in Brazil $1^{77,78}$

\begin{tabular}{llcc}
\hline Target Population & Age Group & Number of Doses & Dose Interval \\
\hline Boys & 12 to $13(2017)$ & 2 & 0 and 6 Months \\
Girls & 9 to 14 & 2 & 0 and 6 Months \\
HIV-Positive People & Men and Women aged 9 to 26 & 3 & $0,2,6$ Months \\
Transplanted from Solid Organs & Men and Women aged 9 to 26 & 3 & $0,2,6$ Months \\
Transplanted Bone Marrow & Men and Women aged 9 to 26 & 3 & $0,2,6$ Months \\
Oncologic Patients & Men and Women aged 9 to 26 & 3 & $0,2,6$ Months
\end{tabular}

Through these actions, the Brazilian Ministry of Health intends to assist around 7.1 million teenagers in 2017 , to reduce incidence of cervical and vulvar cancer in women, to prevent penile and anal cancer and genital warts among men, and to decrease incidence of mouth and oropharynx cancer in both genders ${ }^{79}$.

\section{Reasons for Low Coverage in Brazilian Immunization Program against HPV}

Despite the high investment and logistical complexity involved in the establishment of the national HPV immunization program, the coverage rates are disappointing which certainly represents a barrier to the program effectiveness. The following discussion addresses separately the main reasons for this low performance.

\section{Discontinuance of school-based delivery of vaccines}

The interruption of vaccine application in schools is being considered one of the central reasons for the alarming decline observed in Brazilian vaccination coverage levels ${ }^{80}$. Publications from different countries provide evidence of higher vaccine uptake in schoolbased programs compared to single health facilitybased models ${ }^{81-85}$. Firstly, since schools are attended by a large proportion of adolescents, adoption of active primary prevention - such as the displacement of health professionals to the students' setting - facilitates success 
on vaccine delivery. Immunization in public health posts depend on individual's initiative, relying on advertising campaigns for the success or failure of the action. Secondly, schools also provide a favorable environment for educational measures, which should contribute to students' awareness of HPV and related diseases, highlighting the importance and usefulness of the vaccine and also deconstructing myths that generate uncertainty and fear. As exemplified by Fregnani and collaborators, educational interventions addressed to parents ("Parents Meeting") and pupils ("Educational Week") substantially contributed to the very high three-dose completion rate of $97.2 \%$ obtained in this demonstration study ${ }^{86}$. This supports the need for integration between health and education system to achieve better vaccination indicators. On the other hand, there have been reports that schoolbased program may lead to inequities in vaccine uptake, due to poor access to education and differences in school attendance among different regions countrywide ${ }^{87}$. This does not seem to be the case for Brazil, since high rates of coverage were obtained in the beginning of the HPV immunization programs.

Differently from Brazilian childhood vaccination - performed during first years of child's life and internationally recognized for its excellent coverage and acceptance results ${ }^{88}$, HPV immunization occurs outside the usual age range, representing another relevant obstacle. Additionally, time span between vaccine doses may confuse parents and physician contributing to low compliance $^{89}$. For this reason, it seems more appropriate to the Brazilian reality to associate vaccination in schools with traditional UBS-based immunization, potentially a more effective strategy for developing countries ${ }^{90}$.

\section{Distorted fears and perceptions about the vaccine}

Despite the fact that high efficacy and safety of the vaccine have already been demonstrated, identification of isolated cases of adverse effects in the country combined with indiscriminate spread of rumors in the media and social networks produced a feeling of insecurity. Surveys performed with parents or guardians of pre-adolescent girls in studies conducted in Barretos ${ }^{86}$ and in Roraima ${ }^{91}$, showed that the main reason for refusing to authorize vaccination was fear of adverse effects. This peculiarity is not exclusive of Brazil; other countries, such as Japan ${ }^{92}$ and United States ${ }^{93}$, also face this challenge.

From June 2006 to March 2013, approximately 56 million doses of the quadrivalent HPV vaccine were distributed in the United States and, in the same period, a total of 21,194 adverse events were reported to the Vaccine Adverse Event Reporting System (VAERS), of which $92.1 \%$ were classified as non-serious, reinforcing vaccine safety (94). Even in the face of abundant evidence about benefits of HPV immunization and its low risks, strengthening of anti-vaccine movements has a negative influence on population coverage rates ${ }^{95,96}$.
Misperceptions and some prejudices may also be an obstacle to user's adherence. In Brazil, a crosssectional study conducted in 2016, in Roraima, submitted 797 parents to a questionnaire assessing knowledge, adherence and perceptions about HPV and HPV vaccine. In this survey, parents who believed vaccine offered for free by the SUS was of poor quality had a significantly greater risk of not authorizing vaccination ${ }^{91}$. In addition, since this vaccine is related to a sexually transmitted infection, there is a greater contribution of socioeconomic factors, cultural differences, individual opinions and even a low level of trust in public healthcare.

\section{Lack of knowledge about HPV and HPV vaccine}

According to several studies, worldwide knowledge about HPV is generally poor $(97 ; 98)$; in Brazil, the few existing publications reveal the same situation ${ }^{99-101}$. Although it seems intuitive at first, association between poor knowledge about HPV and the low acceptability of the vaccine remains controversial: studies from Turkey ${ }^{102}$, Netherlands ${ }^{103}$, Indonesia ${ }^{104}$ and United States ${ }^{105}$ found high vaccine acceptability even in a population sample with limited knowledge of HPV and cervical cancer; on the other hand, some authors classify awareness about HPV as a predictor of intention to receive the vaccine ${ }^{106}$. Despite such disagreements, nearly all of these studies highlight the importance of improving educational measures related to HPV and HPV vaccine.

Popular beliefs about the vaccine may have a stronger influence on its compliance than the formal understanding of the virus and its associated diseases ${ }^{107}$. One example is the perception of immunization as beneficial, associated with increased approval of the HPV vaccine in different studies ${ }^{103,108,109}$ worldwide. In Brazil, one study found that the factors with greatest influences on acceptability were knowledge that HPV infection is common, that the vaccine is effective and that its purpose is to prevent cervical cancer. Moreover, the parents' understanding that the HPV vaccine is important for the health of their daughters was considered a positive predictive factor for vaccination ${ }^{91}$. However, even in an educated population, implementation of a vaccination program does not guarantee a satisfactory level of knowledge without adequate advertising strategy ${ }^{86}$. For this reason, it is imperative that vaccination campaigns provide the population and health professionals with relevant information which takes into account not only technical aspects related to HPV and cervical cancer, but also the relevance of this vaccine, its safety, its efficacy, its availability and the age groups of interest. Therefore, the central role of schools is again emphasized, since preadolescents may receive this information at classroom and transmit it to parents at home ${ }^{86}$, increasing the likelihood of adherence to the vaccine. Finally, vaccination campaigns must be adequate to the reality of each region, given the cultural heterogeneity of the Brazilian population. Thus, 
further studies are warranted.

\section{Perspectives for the Brazilian HPV immunization program}

The Brazilian HPV immunization program may be considered recent when compared to countries with greater experience in this field, such as Australia, Sweden and Denmark. In addition, the great extension of the country, socioeconomic differences between regions and barriers to access education and health make the challenge of vaccinating adolescents even more complex, both logistically and financially. Some factors can be considered decisive for the long-term success of the program, as follows.

\section{Improving Vaccine Uptake}

Vaccine administration to a high number of people is a key element in the protective effect of immunization, obtained by the so-called "group immunity". As shown, vaccination coverage in Brazil is still far from the aimed target aimed. Therefore, a combination of strategies should be implemented ${ }^{110}$ :

1) integration between ministries of health and education for maintenance of vaccination in schools at large, evaluated as more effective than administration in health care centers only;

2) development of educational strategies to increase awareness and knowledge about HPV and HPV vaccine and to avert fears and misperceptions. Such actions should ideally take place in schools, yet other media resources may be included in appropriate dissemination of information, especially television, radio, social networks and government pages;

3) formulation of official guidelines for physicians - providing scientific evidence about efficacy, safety and eligible population for HPV vaccine - to stimulate the medical recommendation.

\section{Sustainability of the program}

The long-term sustainability of national program also depends on organizational components. One is the technology-transfer for self-sufficient vaccine production by the country. The Brazilian government has been working on this agenda since 2013, when the US company Merck, Sharp \& Dohme (MSD) established a technologytransfer agreement with Butantan Institute aiming to produce the vaccine at a lower $\operatorname{cost}^{111}$. Another item is implementation of a national electronic immunization registry, a beneficial tool for monitoring vaccination performance ${ }^{112}$, providing information on the number of delivered doses, coverage rates, budget estimates and locations with greater deficiency ${ }^{113}$. The Brazilian Information System of the National Immunization Program (SI-PNI), however, still lacks technological improvements, because many UBSs do not dispose the resources to its access; moreover, in many school-based vaccination records to the system are registered on paper forms ${ }^{114}$. Thus, a combined strategy aimed to achieve improvements in these logistical areas - independence in vaccine production and integration of vaccine monitoring systems - is crucial for the continuation of the program in the next years.

\section{CONCLUSION}

Costs to implement HPV vaccination programs for many LMICs remain an important ongoing investment and potential financial barrier. Although significant progress has been made to achieve lower prices for the vaccine, many middle-income countries are ineligible for financial alternatives offered through GAVI. Besides cost-related issues, these countries may experience sociocultural, health systems and political barriers to deliver and sustain HPV vaccination programs and opportunities to support these countries should be explored.

HPV vaccination has yielded positive results, markedly reducing the incidence of anogenital warts, HPV infection and premalignant cervical lesions, a clear and steady demonstration of the effectiveness of HPV prophylactic vaccination. It should be noted that, in spite of evidence of herd immunity among unvaccinated subjects, it is limited to females and heterosexual males in age groups close to that of the vaccinated subjects and dependent of high vaccine coverage: MSM and several high-risk groups, as immunosuppressed patients, are still being overlooked by the predominant HPV vaccination policies worldwide, perpetuating inequality in health care. Although high coverage could potentially extend herd immunity, attaining the necessary rates is a challenge for most countries. Besides, it does not prevent from exposure from potentially infected individuals of different origins and vaccination status. Therefore, it is recommended that HPV vaccination is extended at least to males and immunosuppressed patients.

In Brazil, it is important to emphasize the great benefit of providing immunization at the national level as a primary prevention measure against cervical cancer, a highly prevalent neoplasm among women. However, vaccination against HPV still faces several challenges: the country's large territorial extension, socio-economic barriers, and difficulties in articulating the health system. Moreover, there are problems inherent to the program itself, such as the interruption of vaccination in schools, fears and distorted perceptions of users and the general lack of knowledge about HPV and the vaccine. Therefore, Brazilian authorities must adopt specific strategies to overcome these issues and reestablish high coverage rates. Thus, more studies should be carried out, focusing not only on analysis of problems faced by the program but also on the evaluation of its effectiveness, such as monitoring the HPV infection and HPV-related disease prevalence countrywide. 


\section{REFERENCES}

1. Herrero R, González P, Markowitz LE. Present status of human papillomavirus vaccine development and implementation. Lancet Oncol. 2015;16(5):e206-e16. doi: 10.1016/S1470-2045(14)70481-4.

2. Garland SM, Kjaer SK, Munoz N, Block SL, Brown DR, DiNubile MJ, et al. Impact and effectiveness of the quadrivalent human papillomavirus vaccine: a systematic review of 10 years of real-world experience. Clin Infect Dis. 2016;63(4):519-27. doi: 10.1093/cid/ciw354.

3. Bollerup S, Baldur-Felskov B, Blomberg M, Baandrup L, Dehlendorff C, Kjaer SK. Significant reduction in the incidence of genital warts in young men 5 years into the Danish Human Papillomavirus Vaccination Program for Girls and Women. Sex Transm Dis. 2016;43(4):238-42. doi: 10.1097/OLQ.0000000000000418.

4. Dominiak-Felden G, Gobbo C, Simondon F. Evaluating the Early Benefit of Quadrivalent HPV Vaccine on Genital Warts in Belgium: A Cohort Study. Plos One. 2015 Jul;10(7). doi: 10.1371/journal.pone.0132404.

5. Wangu Z, Hsu KK. Impact of HPV vaccination on anogenital warts and respiratory papillomatosis. Hum Vaccin Immunother. 2016;12(6):1357-62. doi: 10.1080/21645515.2016.1172754.

6. Audisio RA, Icardi G, Isidori AM, Liverani CA, Lombardi A, Mariani L, et al. Public health value of universal HPV vaccination. Crit Rev Oncol Hematol. 2016;97:157-67. doi: 10.1016/j.critrevonc.2015.07.015.

7. Bosch FX, Broker TR, Forman D, Moscicki AB, Gillison ML, Doorbar J, et al. Comprehensive control of human papillomavirus infections and related diseases. Vaccine. 2013;31(Supp1 7):H1-31. doi: 10.1016/j.vaccine.2013.10.003.

8. World Health Organization. International Agency for Research on Cancer. Cancer today. GLOBOCAN 2012. Estimated age-standardized rates (World) of incident cases, both sexes, all cancers excluding non-melanoma skin cancer, worldwide in 2012 [cited 2017 May 10]. Available from: http://gco.iarc.fr/.

9. Schiffman M, Doorbar J, Wentzensen N, de Sanjose S, Fakhry C, Monk BJ, et al. Carcinogenic human papillomavirus infection. Nat Rev Dis Primers. 2016;2:16086. doi: 10.1038/ nrdp.2016.86.

10. Beer H, Hibbitts S, Brophy S, Rahman MA, Waller J, Paranjothy S. Does the HPV vaccination programme have implications for cervical screening programmes in the UK? Vaccine. 2014;32(16):1828-33 doi: $10.1016 / \mathrm{j}$. vaccine.2014.01.087.

11. Sando N, Kofoed K, Zachariae C, Fouchard J. A reduced national incidence of anogenital warts in young Danish men and women after introduction of a national quadrivalent human papillomavirus vaccination programme for young women--an ecological study. Acta Derm Venereol. 2014;94(3):288-92. doi: 10.2340/00015555-1721

12. Hariri S, Bennett NM, Niccolai LM, Schafer S, Park IU, Bloch KC, et al. Reduction in HPV 16/18-associated high grade cervical lesions following HPV vaccine introduction in the United States-2008-2012. Vaccine. 2015;33(13):1608-13. doi: 10.1016/j.vaccine.2015.01.084.

13. Prue G, Lawler M, Baker P, Warnakulasuriya S. Human papillomavirus (HPV): making the case for 'Immunisation for All'. Oral Dis. 2017;23(6):726-730. doi: 10.1111/odi.12562.

14. Wigle J, Coast E, Watson-Jones D. Human papillomavirus
(HPV) vaccine implementation in low and middle-income countries (LMICs): Health system experiences and prospects. Vaccine. 2013;31(37):3811-7. doi: 10.1016/j. vaccine.2013.06.016.

15. Nicol A, de Andrade C, Russomano F, Rodrigues L, Oliveira N, Provance D, et al. HPV vaccines: their pathology-based discovery, benefits, and adverse effects. Ann Diagn Pathol. 2015;19(6):418-22. doi: 10.1016/j.anndiagpath.2015.07.008.

16. Ferlay J, Soerjomataram I, Ervik M, et al. GLOBOCAN 2012 v1.0, Cancer Incidence and Mortality Worldwide: IARC CancerBase No. 11. Lyon (France): International Agency for Research on Cancer; 2013 [Cited 2017 May 2]. Available from: Available from: http://onlinelibrary.wiley. com/doi/10.1002/ijc.29210/full. doi: 10.1002/ijc.29210.

17. Arbyn M, Castellsagué X, de Sanjosé S, Bruni L, Saraiya M, Bray F, et al. Worldwide burden of cervical cancer in 2008. Ann Oncol. 2011;22:2675-86. doi: 10.1093/annonc/mdr015.

18. Mathew A, George PS. Trends in incidence and mortality rates of squamous cell carcinoma and adenocarcinoma of cervix - worldwide. Asian Pac J Cancer Prev. 2009;10:64550. Available from: http://journal.waocp.org/article 24982 16a547d046cf7e32b65e3096a9f8b3d6.pdf.

19. Brown RE, Breugelmans JG, Theodoratou D, Bénard S. Costs of detection and treatment of cervical cancer, cervical dysplasia and genital warts in the UK. Curr Med Res Opin 2006;22:663-70. doi: 10.1185/030079906X99972.

20. Insinga RP, Dasbach EJ, Elbasha EH. Assessing the annual economic burden of preventing and treating anogenital human papillomavirus-related disease in the US: analytic framework and review of the literature. Pharmacoeconomics 2005;23(11):1107-22. doi: 10.2165/00019053-20052311000004 .

21. WHO World Health Organizatio. Vaccine in National Immunization Programme update [cited 2017 May 2]. Available from: http://www.who.int/immunization/ monitoring surveillance/VaccineIntroStatus.pptx.

22. Markowitz LE, Tsu V, Deeks SL, et al. Human papillomavirus vaccine introduction - the first five years. Vaccine. 2012;30(Suppl 5):F139-48. doi: 10.1016/j. vaccine.2012.05.039.

23. Dorji T, Tshomo U, Phuntsho S, Tamang TD, Tshokey T, Baussano I, et al. Introduction of a National HPV vaccination program into Bhutan. Vaccine. 2015;33(31):3726-30. doi: 10.1016/j.vaccine.2015.05.078.

24. Binagwaho A, Ngabo F, Wagner CM, Mugeni C, Gatera M, Nutt CT, et al. Integration of comprehensive women's health programmes into health systems: Cervical cancer prevention, care and control in Rwanda. Bull World Health Organ. 2013;91:697-703. doi: 10.2471/BLT.12.116087.

25. Kane M, Serrano B, de Sanjose S, Wittet S. Implementation of HPV immunization in the developing world. Vaccine. 2012;30(S5):F192-200. doi: 10.1016/j.vaccine.2012.06.075.

26. GAVI The Vaccine Alliance. Gavi's Mission [cited 2017 May 2]. Available from: http://www2.paho.org/hq/index. php?option $=$ com_content $\&$ view $=$ article $\& i d=9562 \&$ Itemid $=40717$ \&lang $=\mathrm{pt}$.

27. GAVI. The Vacinne Alliance. GAVI takes first steps to introduce vaccines against cervical cancer and rubella. Available at: http://www.gavi.org/library/news/pressreleases/2011/gavi-takes-first-steps-to-introduce-vaccinesagainst-cervical-cancer-and-rubella/.

28. Stanford Journal of Public Health. Gardasil versus GAVI: 
Freitas ACGS, et al. Human papillomavirus vaccination in national immunization programs.

Challenges to Implementing HPV Vaccines in Developing Countries [cited 2017 May 2]. Available from: http:// web.stanford.edu/group/sjph/cgi-bin/sjphsite/gardasilversus-gavi-challenges-to-implementing-hpv-vaccines-indeveloping-countries/.

29. Pan American Health Organization. About PAHO Revolving Fund [cited 2017 May 2]. Available from: http://www2.paho. org/hq/index.php?option $=$ com_content $\&$ view $=$ article $\&$ id $=9$ 562\&Itemid $=40717 \&$ lang $=$ pt.

30. Pan American Health Organization. Vaccines Prices, 2017. [cited 2017 May 2]. Available from: http://www2.paho.org/ hq/index.php?option=com_docman\&task=doc_download\& gid $=38122 \&$ Itemid $=270 \&$ lang $=$ en .

31. Sankaranarayanan R, Bhatla N, Basu P. Current global status \& impact of human papillomavirus vaccination: Implications for India. Indian J Med Res. 2016;144(2):169-80. doi: 10.4103/0971-5916.195023

32. Argentina. Ministerio de Salud. Presidencia de la Nación. Vacuna VPH [cited 2017 April 13]. Available from: http://www.msal.gob.ar/index.php/component/content/ article/48/269-vacuna-vph.

33. Brasil. Ministério da Saúde. Meninos começam a ser vacinados contra HPV na rede pública de saúde. [citado 13 abr. 2017]. Disponível em: http://portalms.saude.gov. br/noticias/agencia-saude/27183-meninos-comecam-a-servacinados-contra-hpv-na-rede-publica-de-saude.

34. Government of Canada. An Advisory Committee Statement (ACS) National Advisory Committee on Immunization (NACI). Update on the recommended Human Papillomavirus (HPV) vaccine immunization schedule. [cited 2017 April 30]. Available from: https://www.canada.ca/en/public-health/ services/publications/healthy-living/update-recommendedhuman-papillomavirus-vaccine-immunization-schedule.html.

35. Gobierno de Chile. Ministerio de Salud. Vacunación contra el virus del papiloma humano [cited 2017 April 13]. Available from: http://web.minsal.cl/vacunacion-contra-el-virus-delpapiloma-humano/?s=Virus+del+Papiloma+Humano.

36. Gobierno de Colombia. Ministerio de Salud y Protección Social. Vacuna contra el cáncer de cuello uterino [cited 2017 April 13]. Available from: https://www.minsalud.gov. $\mathrm{co/salud/publica/Vacunacion/Paginas/ABC-de-la-vacuna-}$ contra-el-cancer-cuello-uterino.aspx.

37. El portal único del gobierno. Virus del Papiloma Humano (VPH) o papilomavirus [2017 May 2]. Available from: http:// www.gob.mx/salud/articulos/virus-del-papiloma-humanovph-o-papilomavirus.

38. Paraguay. Ministerio de Salud Pública y Bienestar Social. Programa Ampliado de Immunizaciones de Paraguay. Vacunacion contra Virus de Papiloma Humano [cited 2017 April 13]. Available from: http://www.mspbs.gov.py/pai/ images/enfermedades/vph_2013.pdf.

39. Panamá. Gobierno de la República de Panamá. MINSA lanza vacuna contra Virus del Papiloma Humano (VPH) en niños [cited 2017 May 2]. Available from: http://www.minsa.gob. $\mathrm{pa} /$ noticia/minsa-lanza-vacuna-contra-virus-del-papilomahumano-vph-en-ninos.

40. Perú. Ministerio de Salud. Minsa vacunará a las niñas de quinto grado de primaria contra el Virus del Papiloma Humano [cited 2017 April 30]. Available from: http://www. minsa.gob.pe/?op=51\&nota $=22410$.

41. Centers for Disease Control and Prevention. Humam Papillomavirus (HPV) [cited 2017 April 30]. Available from: https://www.cdc.gov/hpv/.

42. Uruguay. Ministerio de Salud Publica. Salud Pública recomienda que niñas de 12 años se vacunen contra Virus del Papiloma Humano [2017 April 30]. Available from: http:// www.msp.gub.uy/noticia/vacunas.

43. Ministerium Frauen Gesundheit. Österreichischer Impfplan 2017 [cited 2017 April 30]. Available from: http://www.bmgf. gv.at/home/Impfplan.

44. Denmark. Statens Serum Institut. Vaccination mod livmoderhalskræft (HPV). Available from: https://www.ssi. $\mathrm{dk} /$ Vaccination/Boernevaccination/Vaccination $\% 20 \bmod \% 20$ livmoderhalskraeft.aspx.

45. Institut National du Cancer. La vaccination contre les infections liées au papillomavirus humains (HPV) pour prévenir le cancer du col de l'utérus [cited 2017 April 30]. Available from: http://www.e-cancer.fr/Professionnels-desante/Facteurs-de-risque-et-de-protection/Agents-infectieux/ Prevenir-le-cancer-du-col-de-l-uterus.

46. Deutsches Krebsforschungszentrum. HPV-Impfung: Antworten auf häufige Fragen [cited 2017 April 30]. Available from: https://www.krebsinformationsdienst.de/vorbeugung/ risiken/hpv-impfung.php.

47. Ireland's Health Service Executive. HPV vaccine [cited 2017 April 30]. Available from: http://www.hse.ie/eng/health/ immunisation/pubinfo/schoolprog/HPV/HPV/.

48. Brasil. Ministério da Saúde. Serviço Nacional de Saúde. Novo plano de vacinas [citado 14 abr. 2017]. Available from: https:// www.sns.gov.pt/noticias/2017/01/02/novo-plano-de-vacinas/.

49. University of Oxford. Vaccine Knowledge Project. HPV vaccine (Human Papillomavirus Vaccine) [citede 2017 April 30]. Available from: http://vk.ovg.ox.ac.uk/hpv-vaccine.

50. Australian government. The Department of Health. Human Papillomavirus (HPV) [cited 2017 April 30]. Available from: http://www.health.gov.au/internet/immunise/publishing.nsf/ Content/immunise-hpv.

51. Bruni L, Diaz M, Barrionuevo-Rosas L, Herrero R, Bray F, Bosch FX, et al. Global estimates of human papillomavirus vaccination coverage by region and income level: a pooled analysis. Lancet Global Health. 2016;4(7):E453-E63. doi: 10.1016/S2214-109X(16)30099-7.

52. D'Addario M, Redmond S, Scott P, Egli-Gany D, RiverosBalta AX, Henao Restrepo AM, et al. Two-dose schedules for human papillomavirus vaccine: systematic review and metaanalysis. Vaccine. 2017;35(22):2892-901. doi: 10.1016/j. vaccine.2017.03.096.

53. New Zeland. Ministry of Health. HPV immunisation programme [cited 2017 April 14]. Available from: http:// www.health.govt.nz/our-work/preventative-health-wellness/ immunisation/hpv-immunisation-programme.

54. Mateus M. Jornal da Angola. Aumentam os casos de cancro no colo de útero. J Angola, 16 fev. 2017 [citado 23 maio 2017]. Disponível em: http://jornaldeangola.sapo.ao/reportagem/ aumentam_os_casos_de_cancro_no_colo_do_utero.

55. Arbyn M, Vanden Broeck D, Benoy I, Bogers J, Depuydt C, Praet M, et al. Surveillance of effects of HPV vaccination in Belgium. Cancer Epidemiol. 2016;41:152-8. doi: 10.1016/j. canep.2015.12.011.

56. Mesher D, Panwar K, Thomas SL, Beddows S, Soldan K. Continuing reductions in HPV 16/18 in a population with high coverage of bivalent HPV vaccination in England: an ongoing cross-sectional study. BMJ Open. 2016;6(2):e009915. doi: 10.1136/bmjopen-2015-009915. 
Freitas ACGS, et al. Human papillomavirus vaccination in national immunization programs.

57. Cameron RL, Kavanagh K, Pan JF, Love J, Cuschieri K, Robertson C, et al. Human Papillomavirus Prevalence and Herd Immunity after Introduction of Vaccination Program, Scotland, 2009-2013. Emerg Infect Dis. 2016;22(1):56-64. doi: 10.3201/eid2201.150736

58. Kavanagh K, Pollock KGJ, Potts A, Love J, Cuschieri K, Cubie $\mathrm{H}$, et al. Introduction and sustained high coverage of the HPV bivalent vaccine leads to a reduction in prevalence of HPV 16/18 and closely related HPV types. Brit J Cancer. 2014;110(11):2804-11. doi: 10.1038/bjc.2014.198.

59. Tanton C, Mesher D, Beddows S, Soldan K, Clifton S, Panwar $\mathrm{K}$, et al. Human papillomavirus (HPV) in young women in Britain: Population-based evidence of the effectiveness of the bivalent immunisation programme and burden of quadrivalent and 9-valent vaccine types. Papillomavirus Res. 2017;3:3641. doi: 10.1016/j.pvr.2017.01.001.

60. Tabrizi SN, Brotherton JML, Kaldor JM, Skinner SR, Liu B, Bateson D, et al. Assessment of herd immunity and cross-protection after a human papillomavirus vaccination programme in Australia: a repeat cross-sectional study. Lancet Infect Dis. 2014;14(10):958-66. doi: 10.1016/S14733099(14)70841-2.

61. Donovan B, Franklin N, Guy R, Grulich AE, Regan DG, Ali H, et al. Quadrivalent human papillomavirus vaccination and trends in genital warts in Australia: analysis of national sentinel surveillance data. Lancet Infect Dis. 2011;11(1):3944. doi: 10.1016/S1473-3099(10)70225-5.

62. Ali H, Donovan B, Wand H, Read TR, Regan DG, Grulich AE, et al. Genital warts in young Australians five years into national human papillomavirus vaccination programme: national surveillance data. BMJ. 2013;346:f2032. doi: 10.1136/bmj.f2032.

63. Smith LM, Strumpf EC, Kaufman JS, Lofters A, Schwandt M, Levesque LE. The early benefits of human papillomavirus vaccination on cervical dysplasia and anogenital warts. Pediatrics. 2015;135(5):E1131-E40. doi: 10.1542/peds.20142961.

64. Pollock KGJ, Kavanagh K, Potts A, Love J, Cuschieri K, Cubie H, et al. Reduction of low- and high-grade cervical abnormalities associated with high uptake of the HPV bivalent vaccine in Scotland. Brit J Cancer. 2014;111(9):1824-30. doi: 10.1038/bjc.2014.479.

65. Brotherton JML, Malloy M, Budd AC, Saville M, Drennan KT, Gertig DM. Effectiveness of less than three doses of quadrivalent human papillomavirus vaccine against cervical intraepithelial neoplasia when administered using a standard dose spacing schedule: Observational cohort of young women in Australia. Papillomavirus Res. 2015;1:59-73. doi: 10.1016/j.pvr.2015.05.005.

66. Hariri S, Johnson ML, Bennett NM, Bauer HM, Park IU, Schafer S, et al. Population-based trends in high-grade cervical lesions in the early human papillomavirus vaccine era in the United States. Cancer. 2015;121(16):2775-81. doi: 10.1002/cncr.29266. Epub 2015 Jun 22.

67. Herweijer E, Sundstrom K, Ploner A, Uhnoo I, Sparen P, Arnheim-Dahlstrom L. Quadrivalent HPV vaccine effectiveness against high-grade cervical lesions by age at vaccination: A population-based study. Int J Cancer. 2016;138(12):2867-74. doi: 10.1002/ijc.30035.

68. Mahmud SM, Kliewer EV, Lambert P, Bozat-Emre S, Demers AA. Effectiveness of the quadrivalent human papillomavirus vaccine against cervical dysplasia in Manitoba, Canada. J Clin Oncol. 2014;32(5):438-43. doi: 10.1200/JCO.2013.52.4645.
69. Ogilvie GS, Naus M, Money DM, Dobson SR, Miller $\mathrm{D}$, Krajden M, et al. Reduction in cervical intraepithelial neoplasia in young women in British Columbia after introduction of the HPV vaccine: an ecological analysis. Int J Cancer. 2015;137(8):1931-7. doi: 10.1002/ijc.29508.

70. El-Zein M, Richardson L, Franco EL. Cervical cancer screening of HPV vaccinated populations: Cytology, molecular testing, both or none. J Clin Virol. 2016;76( Suppl 1):S62-8. doi: 10.1016/j.jcv.2015.11.020.

71. Brasil. Ministério da Saúde, Instituto Nacional de Câncer José Alencar Gomes da Silva (INCA). Estimativa 2016: incidência de câncer no Brasil. Rio de Janeiro: INCA; 2015 [citado 24 abr. 2017]. Disponível em: http://www.inca.gov. br/estimativa/2016/estimativa-2016-v11.pdf.

72. Brasil. Ministério da Saúde. Instituto Nacional de Câncer José Alencar Gomes da Silva (INCA). Atlas online de mortalidade. Rio de Janeiro; 2014 [citado 17 mar. 2017]. Disponível em: https://mortalidade.inca.gov.br/MortalidadeWeb/

73. Ayres A, Silva G. Cervical HPV infection in Brazil: systematic review. Rev Saúde Pública. 2010;44(5):963-974. doi: 10.1590/S0034-89102010000500023.

74. Brasil. Ministério da Saúde. SVS/DEVIT/CGPNI. Guia prático sobre HPV: guia de perguntas e respostas para profissional da saúde. Brasília; 2014 [citado 18 mar. 2017]. Disponível em: http://portalarquivos.saude.gov.br/images/ pdf/2014/marco/07/guia-perguntas-repostas-MS-HPVprofissionais-saude2.pdf.

75. Brasil. Ministério da Saúde. Conselho Nacional de Secretarias Municipais de Saúde (CONASEMS). SVS/ DEVIT/CGPNI, PNI: Programa Nacional de Imunizações. Boletim Informativo: Vacinação contra HPV. CONASEMS - Conselho Nacional de Secretarias Municipais de Saúde. Brasília; 2016 [citado 3 maio 2017]. Available from: http:// www.conasems.org.br/wpcontent/uploads/2016/10/images Boletim informativo HPV002-2016.pdf

76. Dobson S, McNeil S, Dionne M, Dawar M, Ogilvie G, Krajden M, et al. Immunogenicity of 2 doses of HPV vaccine in younger adolescents vs 3 doses in young women. JAMA. 2013;309(17):1793. Available from: http://jamanetwork. com/pdfaccess.ashx?url=/data/journals/jama/926887/. doi: 10.1001/jama.2013.1625.

77. Brasil. Ministério da Saúde amplia vacinação em todas as faixas etárias [citado 2 maio 2017]. Disponível em: http:// portalarquivos.saude.gov.br/images/pdf/2017/marco/03/ Novo-calendario-vacinal-de-2017.pdf.

78. Brasil. Ministério da Saúde. Tire dúvidas sobre a vacinação contra o HPV para meninos [citado 2 maio 2017]. Disponível em: http://www.brasil.gov.br/saude/2017/01/tire-duvidassobre-a-vacinacao-contra-o-hpv-para-meninos.

79. Brasil. Ministério da Saúde. Brasil vai incluir meninos na vacinação contra HPV. Brasília; 2016 [citado 19 mar. 2017]. Disponível em: http://portalarquivos.saude.gov.br/images/ pdf/2016/outubro/11/vacinas-para-adolescentes.pdf.

80. Lenharo M. Menor ação das escolas reduziu adesão à vacina de HPV, diz ministério. G1 - Bem Estar. 2016 [citado 4 jun. 2017]. Disponível em: http://g1.globo.com/bemestar/ noticia/2016/06/menor-acao-das-escolas-prejudicou-adesaovacina-de-hpv-diz-ministerio.html.

81. Rehn M, Uhnoo I, Kühlmann-Berenzon S, Wallensten A, Sparén P, Netterlid E. Highest vaccine uptake after school-based delivery - a county-level evaluation of the implementation strategies for HPV Catch-Up vaccination 
Freitas ACGS, et al. Human papillomavirus vaccination in national immunization programs.

in Sweden. PLOS One. 2016;11(3):e0149857. doi: 10.1371/ journal.pone.0149857.

82. Brabin L, Roberts S, Stretch R, BaxterD, Chambers G, Kitchener $\mathrm{H}$, et al. Uptake of first two doses of human papillomavirus vaccine by adolescent schoolgirls in Manchester: prospective cohort study. BMJ. 2008;336(7652):1056-1058. doi: 10.1136/bmj.39541.534109.

83. Brotherton J, Murray S, Hall M, Andrewartha L, Banks C, Meijer D, et al. Human papillomavirus vaccine coverage among female Australian adolescents: success of the schoolbased approach. Med J Austr. 2013;199(9):614-7. doi: $10.5694 / \mathrm{mja} 13.10272$.

84. Lim W, Sears K, Smith L, Liu G, Lévesque L. Evidence of effective delivery of the human papillomavirus (HPV) vaccine through a publicly funded, school-based program: the Ontario Grade 8 HPV Vaccine Cohort Study. BMC Public Health. 2014;14(1):1029. doi: 10.1186/1471-2458-14-1029.

85. Potts A, Sinka K, Love J, Gordon R, McLean S, Malcolm W, et al. High uptake of HPV immunisation in Scotland - perspectives on maximising uptake. Eurosurveillance. 2013;18(39):20593. doi: 10.2807/1560-7917. ES2013.18.39.20593.

86. Fregnani J, Carvalho A, Eluf-Neto J, Ribeiro K, Kuil L, da Silva T, et al. A School-Based Human Papillomavirus Vaccination Program in Barretos, Brazil: final results of a demonstrative study. PLoS ONE. 2013;8(4):e62647. doi: 10.1371/journal.pone.0062647.

87. Vandelaer J, Olaniran M. Using a school-based approach to deliver immunization-Global update. Vaccine. 2015;33(5):719-25. doi: 10.1016/j.vaccine.2014.11.037.

88. World Health Organization (WHO). United Nations Children's Fund (UNICEF). Immunization summary: a statistical reference containing data through 2013. New York: UNICEF; 2014 [cited 2017 May 3]. Available from: http://www.who.int/immunization/monitoring_surveillance/ Immunization_Summary_2013.pdf.

89. Ramos C, Paixão J, Donza F, Silva A, Caçador D, Dias V, et al. Compliance with the child immunization calendar in family healthcare units. Rev Pan-Amaz Saúde. 2010;1(2):5560. doi: 10.5123/S2176-62232010000200006.

90. Ladner J, Besson M, Hampshire R, Tapert L, Chirenje M, Saba J. Assessment of eight HPV vaccination programs implemented in lowest income countries. BMC Public Health. 2012;12(1):370. doi: 10.1186/1471-2458-12-370.

91. Farias C, Jesus D, Moraes H, Buttenbender I, Martins I, Souto M, et al. Factors related to non-compliance to HPV vaccination in Roraima-Brazil: a region with a high incidence of cervical cancer. BMC Health Serv Res. 2016;16(1):417. doi: 10.1186/s12913-016-1677-y.

92. Hanley S, Yoshioka E, Ito Y, Konno R, Hayashi Y, Kishi $\mathrm{R}$ et al. Acceptance of and attitudes towards human papillomavirus vaccination in Japanese mothers of adolescent girls. Vaccine. 2012;30(39):5740-5747. doi: 10.1016/j. vaccine.2012.07.003.

93. Roberts J, Thompson D, Rogacki B, Hale J, Jacobson $\mathrm{R}$, Opel D, et al. Vaccine hesitancy among parents of adolescents and its association with vaccine uptake. Vaccine. 2015;33(14):1748-55. doi: 10.1016/j.vaccine.2015.01.068.

94. Stokley S, Jeyarajah J, Yankey D, Cano M, Gee J, Roark $\mathrm{J}$ et al. Human papillomavirus vaccination coverage among adolescents, 2007-2013, and postlicensure vaccine safety monitoring, 2006-2014 - United States. MMWR.
2014;63(29):620-4. Available from: https://www.cdc.gov/ $\mathrm{mmwr} / \mathrm{pdf} / \mathrm{wk} / \mathrm{mm} 6329 . \mathrm{pdf}$.

95. Poland G, Jacobson R. Understanding those who do not understand: a brief review of the anti-vaccine movement. Vaccine. 2001;19(17-19):2440-5. doi: 10.1016/S0264410X(00)00469-2.

96. Poland G, Jacobson R, Ovsyannikova I. Trends affecting the future of vaccine development and delivery: the role of demographics, regulatory science, the anti-vaccine movement, and vaccinomics. Vaccine. 2009;27(25-26):32404. doi: 10.1016/j.vaccine.2009.01.069.

97. Klug S, Hukelmann M, Blettner M. Knowledge about infection with human papillomavirus: a systematic review. Preventive Med. 2008;46(2):87-98. doi: 10.1016/j. ypmed.2007.09.003.

98. Cuschieri KS, Horne AW, Szarewski A, Cubie HA. Public awareness of human papillomavirus. J Med Screening. 2006;13(4):201-7. Available from: http://journals. sagepub.com/doi/pdf/10.1177/096914130601300408. doi: 10.1177/096914130601300408.

99. Moreira E, Oliveira B, Ferraz F, Costa S, Costa Filho J, Karic G. Knowledge and attitudes about human papillomavirus, Pap smears, and cervical cancer among young women in Brazil: implications for health education and prevention. Int J Gynecol Cancer. 2006;16(2):599-603. doi: 10.1111/j.15251438.2006.00377.x. doi: 10.1111/j.1525-1438.2006.00377.x.

100. Sousa LB, Pinheiro AKB, Barroso MGT. Ser mulher portadora do HPV: uma abordagem cultural. Rev Esc Enferm USP. 2008;42(4):737-43. doi: 10.1590/S008062342008000400017.

101. Osis M, Duarte G, Sousa M. SUS users' knowledge of and attitude to HPV virus and vaccines available in Brazil. Public Health Pract. 2017;48(1):123-33. doi: 10.1590/ S0034-8910.2014048005026.

102. Dursun P, Altuntas B, Kuscu E, Ayhan A. Women's knowledge about human papillomavirus and their acceptance of HPV vaccine. Austr N Z J Obstetr Gynaecol. 2009;49(2):202-6. doi: 10.1111/j.1479-828X.2009.00947.

103. Lenselink C, Gerrits M, Melchers W, Massuger L, van Hamont D, Bekkers R. Parental acceptance of Human Papillomavirus vaccines. Eur J Obstet Gynecol Reprod Biol. 2008;137(1):103-7. doi: 10.1016/j.ejogrb.2007.02.012.

104. Jaspers L, Budiningsih S, Wolterbeek R, Henderson F, Peters A. Parental acceptance of human papillomavirus (HPV) vaccination in Indonesia: a cross-sectional study. Vaccine. 2011;29(44):7785-93. doi: 10.1016/j.vaccine.2011.07.107.

105. Brewer N, Fazekas K. Predictors of HPV vaccine acceptability: A theory-informed, systematic review. Prev Med. 2007;45(2-3):107-114. doi: 10.1016/j. ypmed.2007.05.013

106. Kahn J, Rosenthal S, Hamann T, Bernstein D. Attitudes about human papillomavirus vaccine in young women. Int J STD AIDS. 2003;14(5):300-6. doi: $10.1258 / 095646203321605486$.

107. Chiang E, Baker M, Figueroa-Downing D, Baggio M, Villa L, Eluf Neto J, et al. "Those who love, vaccinate:" parental perceptions of HPV vaccination. J Hum Growth Dev. 2015;25(3):341-50. doi: 10.7322/JHGD.106013.

108. Dempsey A, Abraham L, Dalton V, Ruffin M. Understanding the reasons why mothers do or do not have their adolescent daughters vaccinated against human papillomavirus. Ann Epidemiol. 2009;19(8):531-8. doi: 10.1016/j. 
Freitas ACGS, et al. Human papillomavirus vaccination in national immunization programs.

annepidem.2009.03.011.

109. Lazcano-Ponce E, Rivera L, Arillo-Santillán E, Salmerón J, Hernández-Avila M, Muñoz N. Acceptability of a Human Papillomavirus (HPV) trial vaccine among mothers of adolescents in Cuernavaca, Mexico. Arch Med Res. 2001;32(3):243-7. doi: 10.1016/S0188-4409(01)00277-6.

110. Smulian EA, Mitchell KR, Stokley S. Interventions to increase HPV vaccination coverage: a systematic review. Hum Vaccin Immunother. 2016;12(6):1566-88. doi: 10.1080/21645515.2015.1125055.

111. Baker ML, Figueroa-Downing D, Chiang EDO, Villa L, Baggio ML, Eluf-Neto J, et al . Paving pathways: Brazil's implementation of a national human papillomavirus immunization campaign. Rev Panam Salud Publica. 2015;38(2):163-6. Available from: http://www. scielosp.org/scielo.php?script=sci_arttext\&pid=S102049892015000700010\&lng=en.

112. Centers for Disease Control and Prevention. Development of community and state-based immunization registries. CDC response to a report from the National Vaccine Advisory Committee. MMWR. 2001;50(RR17):1-17. Available from: https:/www.cdc.gov/mmwr/preview/ mmwrhtml/rr5017a1.htm.

113. Danovaro MC. Immunization registries in Latin America and the Caribbean. Geneva: World Health Organization; 2014. Available from: http://www.who.int/immunization/ research/forums and initiatives/01_Danovaro_GVIRF14 Concept_Outline Landscape.pdf.

114. Brasil. Ministério da Saúde. Secretaria de Vigilância em Saúde Departamento de Vigilância de Doenças Transmissíveis. Coordenação-Geral do Programa Nacional de Imunizações. Informe técnico sobre a vacina papilomavírus humano (HPV) na atenção básica. Brasília; 2014. Disponível em: http://portalarquivos2.saude.gov.br/ images/pdf/2015/junho/26/Informe-T--cnico-Introdu----ovacina-HPV-18-2-2014.pdf. 